\title{
Narrativity and Topics in Guerra-Peixe: An analysis of Quarteto Misto
}

\author{
Narratividade e tópicas em Guerra-Peixe: \\ Uma análise do "Quarteto Misto"
}

\author{
Ricardo Tanganelli da Silva \\ Universidade Estadual Paulista (UNESP) \\ ricardo.tanganelli@gmail.com
}

\begin{abstract}
This article presents an analysis of extrinsic narrativity in César Guerra-Peixe's Quarteto Misto (1945), dodecaphonic composition and one of the most representative of this style of the said composer. For that, the research verifies the topical configurations in order to highlight its behavior along the three movements that comprehend the work and put in relief elements that assist the narrative organization. In order to define the key concepts, the references are Agaw $u$ (2009), Almén (2008), Hatten (1994), Monelle (2006), Pasler (2008), Ricoeur (1984), Tarasti (1994), besides analysis of Assis (2006, 2010), Botelho (2013), Egg (2004, 2006), Guerra-Peixe (1971), Hartmann (2011, 2013), Malamut (1999), Coelho de Souza (2011) and Vetromilla (2002). At the end, the article verifies the applicability of narrative analysis in formal articulation and expressive content in order to arouse the reflection of the Brazilian dodecaph onic repertoire of the first half of twentieth-century.
\end{abstract}

Keywords: narrative analysis; topic theory; twelve-tone music; Brazilian twentieth-century music; Guerra-Peixe.

Resumo: Neste artigo, serão analisados elementos de narratividade extrínseca presentes na obra Quarteto Misto (1945) de César Guerra-Peixe (1914-1993), composição de estética serial dodecafônica e uma das mais representativas desta fase do referido compositor. Para tanto, serão verificadas as configurações tópicas a fim de observar seu comportamento ao longo da composição e assim auxiliar na organização da narrativa. Para as definições dos conceitos chave serão utilizadas obras teóricas de referência, tais como Agawu (2009), Almén (2008), Hatten (1994), Monelle (2006), Pasler (2008), Ricoeur (1984), Tarasti (1994), além de análises de Assis (2006, 2010), Botelho (2013), Egg (2004, 2006), Guerra-Peixe (1971), Hartmann (2011, 2013), Malamut (1999), Coelho de Souza (2011)e Vetromilla (2002). Por fim, se verificará a aplicabilidade da análise narrativa na articulação formal e expressiva da obra a fim de suscitar a reflexão acerca do repertório dodecafônico brasileiro da primeira metade do século passado.

Palavras-chave: análise narrativa; teoria das tópicas; dodecafonismo; música brasileira do século vinte; Guerra-Peixe.

\section{MUSICA THEORICA}




\title{
1 - About Narrativity in Music
}

The idea of narrativity in music is a controversial subject and, although by no means new, its application in music analysis is an open field to speculation. Since the mid-1980s onward, the subject gained a new impetus and a great number of papers were published ${ }^{1}$. The conceptualization of specific terms of narrative theory - such as temporality and actoriality, for example - is necessary for an appropriate definition of the discursive phenomena put in the light of musical approach. However, a problem arises: there are two main strategies to deal with the subject. According to Walsh,

\begin{abstract}
one strategy is to reject the normative status of literary narrative, and with it much of the narratological terminology that is, if not exclusively relevant for, certainly native to literary narrative study. The other strategy is to emphasize a hermeneutic model of musicology - in other words, one in which the contexts and processes of interpretation are considered an intrinsic part of the object of study (Walsh 2011, p.51).
\end{abstract}

This leads to an analysis always amenable to several readings depending on the analyst's scope, and must take in account many factors. However,

\begin{abstract}
both strategies shift the focus of attention away from a reductive narrative model of musical discourse in itself, but in opposite directions: the first makes the narrative connection at a lower, more abstract structural level; the second locates it at a higher contextual level that incorporates both musical event and interpretative response. They are also co-dependent strategies, since neither perspective suffices without the other (Walsh 2011, p.51).
\end{abstract}

Therefore, the concept of narrativity, to be valid as an analytic tool, has to consider many theoretical implications. In music, a narrativity based on spatial, temporal, and actorial categories acts like a link between musical events, sections, movements, etc., and provides energy for music to develop over time. In Byron Almén's (2008, p.22) criticism of Eero Tarasti's analysis of Chopin's G minor Ballade $^{2}$, the author says that a narrative "involves the coordination of multiple elements involving different mechanisms of meaning and different levels of focus or temporal scope". This way, he defines the idea of narrativity closely related to the notion of temporality. According to Paul Ricoeur:

Time becomes human time to the extent that it is organized after the manner of a narrative; narrative, in turn, is meaningful to the extent that it portrays the features of a temporal experience (Ricoeur 1984, p.4).

\footnotetext{
${ }^{1}$ Distinguished contributors to the narratological trend include Anthony Newcomb, Peter Kivy, Susan McClary, Fred Maus, Robert Hatten and Eero Tarasti.

2 The referred analysis is presented in Eero Tarasti's book A Theory of Musical Semiotics (1994).
} 
However, by articulating the temporal events in the space of musical composition, narrative becomes a structural data. According to Pasler,

a narrative is also a kind of structure. As a structure, considered by some as independent of any medium, it must have wholeness (in that its events must be related or mutually entailing), transformation, and self-regulation (i.e., selfmaintenance and closure, that is, all transformations must engender only elements already within the system) (Pasler 2008, p.31).

Thus, in general terms, a narrative "is a kind of discourse, a manifestation of some content in a given medium" (ibid., p. 27), and as a discourse is "fundamentally dependent on the listener's, analyst's, and/or performer's interpretation" (Almén 2008, p.21). In addition, it is important to emphasize that an analysis of the narrative of a work will always be the result of the identification of the relationship between elements that articulate the musical events, related to the idea of actoriality ${ }^{3}$.

\section{2 - About the Topic Theory}

Among the procedures of motif recognition that help the analysis of a narrative in a given work, the Topic Theory turns out to be a very useful resource ${ }^{4}$. Although conceived for the analysis of Classic and Romantic music, its premises are found in later works and form a kind of compositional intertextual imaginary level. In general terms, the topics are:

“[...] characteristic figures [...] associated with various feelings and affections [...]. They are designated here as topics - subjects for musical discourse" (Ratner apud Agawu 2009, p.42).

Leonard Ratner categorized these figures in his book Classic Music: Expression, Form and Style (1980) and led to later discussion by several authors (see Agawu 1991, Klein 2004, 2005, Micznik 2001, Monelle 1992, 2000). However, especially in Robert Hatten's book Meaning in Beethoven: Markedness, Correlation,

\footnotetext{
3 "Actoriality forms one of the most pertinent and most clearly foregrounded levels of the work. The most obvious - emotional and phenomenal - Firstness impression is that this level is based on a few clear-cut actors" (Tarasti 1994, p.161). How ever, "actorial elements are not essential to music narrative, but are one of those devices that can be successfully translated from literary narrative" (Almén 2008, p.23).

4 "The concept of topic provides us with a (speculative) tool for the imaginative description of texture, affective stance, and social sediment in classic music" (Agawu 2009, p.42).
} 
and Interpretation (1994), the topical analysis gains new impetus from a broader theory of expressive meanings that considers, among other things

how oppositions of musical elements give rise to expressive oppositions, how the juxtaposition of expressive types brings about new expressive interpretations, and how individual, piece-specific correlations become encoded into a conventional stylistic feature (type) that in turn serves as raw material for new expressive correlations (Almén 2008, p.72).

Hatten starts from the principle of the opposition between networks of meanings by pointing out that Ratner's topics may involve a mixture of categories like "style, word painting, motivic association, social occasion, and level of discourse (high / middle / low) (Hatten 1994, p. 74-75). According to this concept, topics become

richly coded style types which carry features linked to affect, class, and social occasion such as church styles, learned styles, and dance styles. In complex forms these topics mingle, providing a basis for musical allusion (Hatten 1994, p. x).

Thus, topics confer particular characteristics for each element of motif, helping its recognition in the musical discourse and strengthening the idea of opposition that articulate in the compositional narrative.

\section{3 - The Quarteto Misto: Background}

The Quarteto Misto ("Mixed Quartet"), written in May 7 1945, for flute, clarinet, violin and cello, is a work that belongs to the so-called "dodecaphonic phase" $^{\prime 5}$ of the Brazilian composer César Guerra-Peixe (1914-1993). Best known as a nationalist composer, the period between the years 1944 and 1949 saw a flourishing of dodecaphonic works and this quartet is one Guerra-Peixe's most valuable compositions. The music exemplifies the use of new compositional techniques spread in Brazil, a few years earlier, by the German theorist and composer H. J. Koellreuter (1915-2005) who influenced a great number of composers $^{6}$. Enjoying its golden age in Europe, the dodecaphonic technique had a remarkable influence on the works of Cláudio Santoro (1919-1989), Eunice

\footnotetext{
${ }^{5}$ According to the composer himself: "Works of the so called 'dodecaphonic phase' (1944-1949), w orks of 'nationalist phase' (1949 forw ard) and works of 'initial phase' (until 1944)" (Egg 2004). ${ }^{6}$ For further reading on the subject, see Coelho de Souza, Rodolfo - A recepção das teorias do dodecafonismo nos últimos Quartetos de cordas de Cláudio Santoro. Revista Brasileira de Música. Rio de Janeiro, v. 24, n. 2, p. 329-350, Jul./Dez. 2011.
} 
Catunda (1915-1990) and Edino Krieger (1928), all of them, together with GuerraPeixe, members of the Grupo Música Viva .

Together with Guerra-Peixe, Claudio Santoro, Eunice Katunda and other young composers, Koellreutter was responsible for one of the most important scenarios in the history of Brazilian music - the foundation of the Grupo Música Viva. Aiming the creation and dissemination of the contemporary production, the Música Viva Group, through its actions, for instance publishing several manifestos throughout the decade of 1940, promoted a revolution in the Brazilian compositional procedures of that time, introducing the twelve-tone technique recently created by Schoenberg (Hartmann 2011, p.98).

Dodecafonism represented the extreme opposite ideal of the nationalist composers from that time, causing big clashes between the defenders and the opponents of the system ${ }^{8}$. Anyway, it aroused interest from various composers willing to know what was new in the European Vanguard. According to GuerraPeixe, in 1944, he started to attend the private course of H. J. Koellreutter and few months later, he adopted the twelve-tone technique. From this moment on, his music became rhythmically unstable, as he used excessively complex rhythms. At that time, he had no concerns for a national musical idiom. His aesthetical thinking may be summarized as follows: a motif, a chord or a rhythm should never be stated twice equal, or even similar, because any similarity would be no more than mere naiveté. Later Guerra-Peixe will recall this period with the following critical view:

This radical attitude resulted in insurmountable problems, especially concerning rhythm, evincing an impression of lack of formal unity. One of the most representative works of that time is the Quarteto Misto, written in 1945, whose difficulties, almost without any support in tempo, made it impossible to be performed, in both Rio de Janeiro and Buenos Aires. The Quarteto Misto is like a Kandinsky painting that was on display at the Askanazy Gallery ${ }^{9}$ on those days. Nevertheless, the twelve-tone technique was restrained to the role of assuring the sense of atonality, never achieving a real constructive value for the whole. (Guerra-Peixe, 1971).

\footnotetext{
${ }^{7}$ For further reading, see Kater, Carlos - Música Viva e H.J. Koellreutter. Movimentos em direção à modernidade. São Paulo: Musa Editora e Através, 2001.

8 About this topic, the "Carta aberta aos músicos e críticos do Brasil" written in 1950 by the composer Camargo Guarnieri (1907-1993), probably represents the most radical oppositional attitude to the technique. For more information read Egg, André - A carta aberta de Camargo Guarnieri. Rev. cient. /FAP. Curitiba, v.1, p.1-12, jan./dez. 2006.

${ }_{9}^{9}$ Founded in 1945, the Galeria Askanasy is considered the first Brazilian gallery specialized in contemporary art. Available at: <http://enciclopedia.itaucultural.org.br/termo5400/galeriascomerciais-no-rio-de-janeiro-e-em-sao-paulo-ate-1970>. Access June 26, 2017.
} 
In other testimonies, Guerra-Peixe also shows a great deal of concern with the complications that this style of music brought to his writing, especially regarding rhythm. In a letter to the musicologist Curt Lange (1903-97) ${ }^{10}$, he reveals more details of his opinion about the dodecaphonic technique ${ }^{11}$ :

About the rhythm in twelve-tone music [...] this is a weak point that I have shown, but what my colleagues and friends seem to disagree with, what bothers me so far, is the prejudice to avoid sequences, especially rhythmic ones. I have the impression that we are getting so full of philosophical ideals that we finally forget the music. Because, my friend, in the Quarteto Misto and the Noneto, I went too far in order to never repeat melodic or rhythmic ideas. As a result, I did everything so complicated, that the Quarteto Misto was rehearsed many times in Buenos Aires and they were still not able to play it, as Eitler told me. [...]. But, in the Duo para flauta e violino (1947), the rhythm begins to be stable. The Quarteto and Peça pra Dois Minutos, it seems to me that they already have rhythm. But I keep improving that part. There are, nevertheless, many more rhythms and melodic sequences. However, I see that most of the time, in works based on twelve-tone rows, the sequence do not have space. They convey the aesthetic "advertising" that atonal music is arrhythmic. [...] I find it more the lack of construction than the "aesthetic concept". Because you can give rhythm to a w ork without using the exaggeration of abusive sequences. I trust your culture and your sincerity to free me from this great doubt. Speak frankly, because I will not divulge your opinion to anyone - if you imagine that it will hurt others who still do not care about the problem. Ihave been discussing the subject. But my opinion did not find resonance. They philosophically say that my atonal music has to be like this because today's world is unbalanced, tortured! Well, nowadays the world is only shown by that aspect but the struggle, motives and goals are the same at any time, don't you think? Or am I talking nonsense? Atonal composers, it seems, have not yet noticed that most popular songs of today societies are more rhythmic (swing, samba, tango, rumba, conga, quaracha [sic], Mexican waltzes, just to talk about Latin America) than those of eras before. If people feel this the rhythm factor, why should our music not reflect that feeling?(Guerra-Peixe apud Assis 2006, p.198-199).

In order to make the performance easier, after he realize the technical difficulties of the first version, Guerra-Peixe wrote a second version of the Quarteto Misto ${ }^{12}$ (as of other dodecaphonic works ${ }^{13}$ ), dated December 8, 1947.

\footnotetext{
${ }^{10}$ Letter from Guerra-Peixe to Curt Lange. Rio de Janeiro, May 9, 1947.

${ }^{11}$ For further reading about the dodecaphonic technique in Brazil and its theoretical and technical features, see Hartmann, Ernesto - O Melos e Harmonia Acústica (1988) de César Guerra-Peixe, Koellreutter e Hindemith: similaridades e princípios básicos. Per Musi, n.27, 2013, p.50-60.

${ }_{12}$ Cf. Assis 2006, p. 174; 2010, p.6; and Malamut 1999, p.8.

${ }^{13}$ Other reformulated works are: Noneto, Quatro Bagatelas (piano), Quatro Peças Breves (piano), Três peças (bassoon and piano), Duo (violin and viola), Música (violin and viola), Música (flute and piano), Allegretto con moto (flute and piano), Seis Instantâneos (orchestra), Marcha Fúnebre e Scherzetto (orchestra), Trio de Cordas (strings trio) (Botelho 2013, p.73).
} 
According to the composer,

there is more and more insistence on the objectification of "nationalized" melodic contours by creating tonal centers. W orks become gradually more accessible, at least in relative terms. [...]. However, dissatisfaction persists. A period of crisis occurs in composition, motivating the author to reformulate some of his works, especially if they accuse the greatest rhythmic dilution (Guerra-Peixe 1971, p.3).

The difficulties to put together the technical demands required to execution, combined with the quick decay of the dodecaphonic aesthetics and the divulgation and consequent acceptance of works with nationalist flavor perhaps with some dose of ideological propaganda -, obscured the output of this period, making the access to his dodecaphonic works very restrict. According to Malamut, this Quartet had its debut only many years later ${ }^{14}$ :

It was only many years later, in 1996, that the work was finally presented in Concert at the Sala Cecília Meireles, in Rio de Janeiro, by the Camerata Contemporânea do Rio de Janeiro (Malamut 1999, p. 2).

\title{
4 - The Narrative Analysis
}

In the analysis, it is evident the use of certain intervals in its structuring notably seconds major and minor, frequently presented in octaves, generating intervals of sevenths and ninths - as result of a search for consistence and organization, very likely a Webern's devotion. The rhythmic aspect, as already mentioned, is perhaps the most complex structural element of the composition, since in addition to the constant interaction between binary and ternary figures, hemiolas and overlapping of tuplets, it presents a great number of phrases initiated in the upbeats. According to Assis (2010, p.64):

\begin{abstract}
The lack of support "in tempo" or in other words, replacing sound by silence (rests) in the Quarteto's strong beats not only hardens the musicians' involvement but also tends to unbalance the metric. The score of this work presents a great variety of rhythmic configurations, almost never repeated, responsible for an unstable musical discourse and a sensation of acceleration of the time.
\end{abstract}

Some of the features shown in Example 1 depict the idea of a fluid and non-articulated temporality based on structural devices.

\footnotetext{
14 "Scheduled for a concert in 1945 at the Escola Nacional de Música in Rio de Janeiro and later at the Agrupación Nueva Música in Buenos Aires, both executions did not take place due to the difficulties for musicians to perform the work" (Guerra-Peixe apud Egg 2004, p.2017).
} 

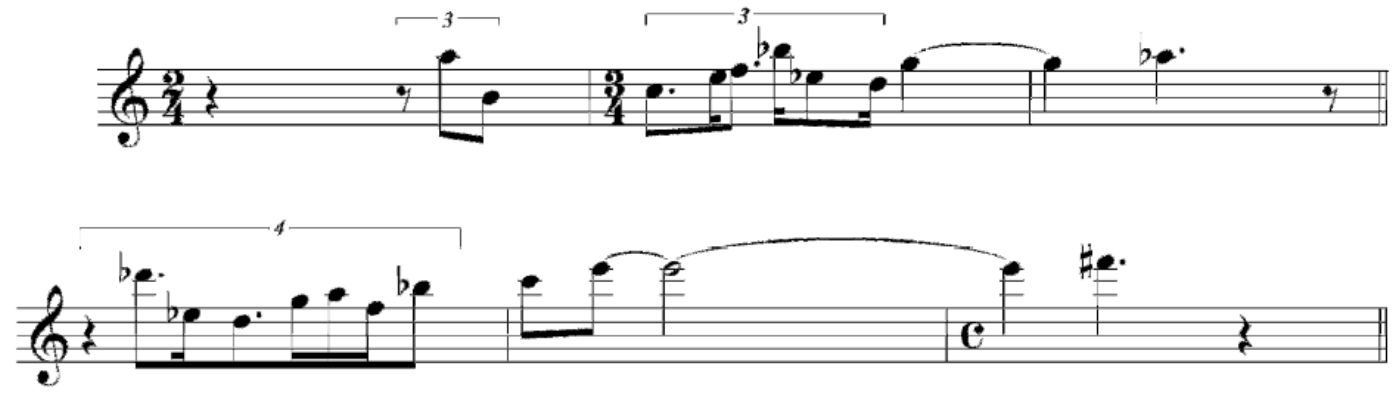

Example 1: Two fragments ${ }^{15}$ exemplifying the rhythm complexity of Quarteto Misto

The layered structure of the piece comprehends four actorial elements, each one represented by a different instrument, in dialogue with the twelve-tone series in different ways. Much of the composition clearly marks contrasts between one instrumental group and another. Considered as one of the premises of narrative analysis ${ }^{16}$, the conflict between these actors are explored both from the point of view of the elaboration of musical motifs and the general organization in contrasting movements.

The twelve-tone series has a quite free treatment thanks to the non-radical view of serial composition that Koellreuter used to teach in Brazil. In the first movement, the series that will serve as compositional material, results from the juxtaposition of two clearly distinctive motivic units (see Example 2). Moreover, the 12th pitch of the series appears only when the phrase returns to the first motif, suspending for a while the expectation of the serial composition.

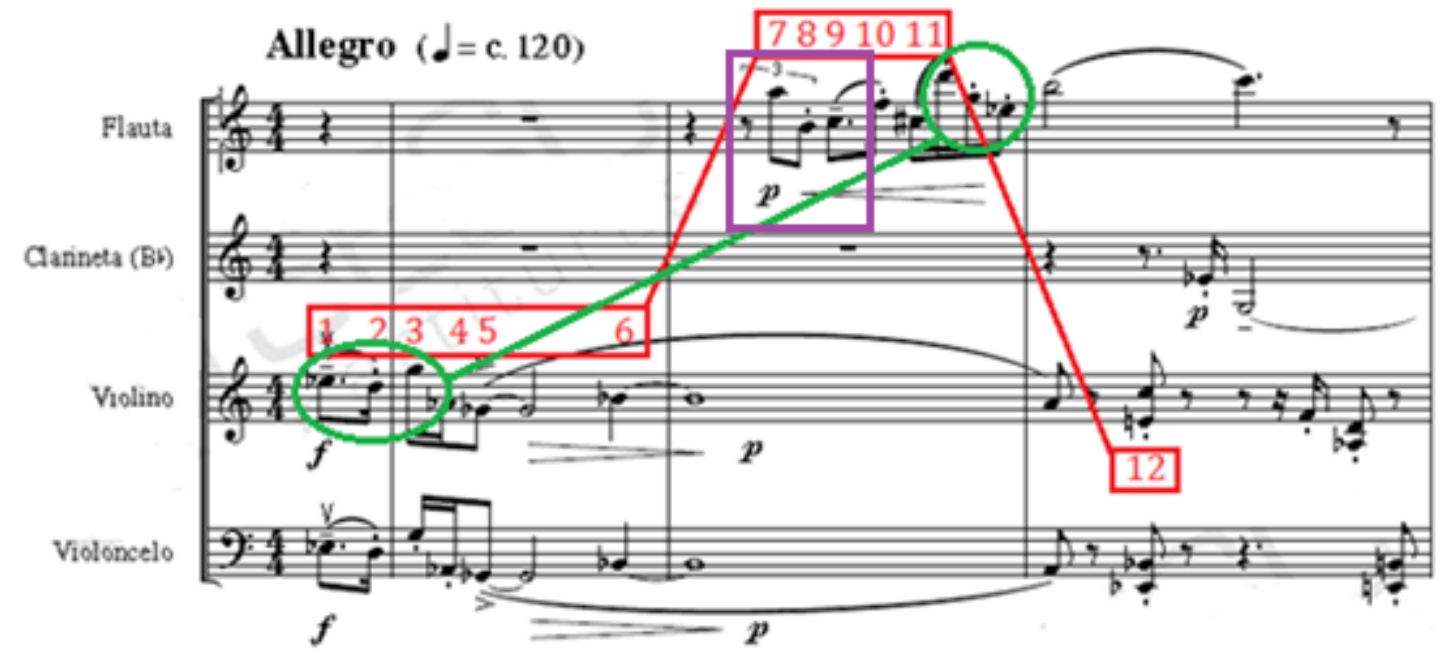

Example 2: First movement, initial bars

15 These examples are extracted from an autograph that assembles eighty examples from GuerraPeixe w orks, demonstrating his aesthetic evolution until April 1947. Division of Music and Sound File of the National Library, Guerra Peixe Collection: Rio de Janeiro apud Vetromilla 2002, p.23. 16 "Along with the coordination of multiple levels and musical features, the central role of conflict in narrative analysis must be emphasized" (Almén 2008, p.23). 
From these two motifs derives the whole movement, presenting constant variations, but always maintaining its intelligibility. Its rhythmic configuration, allied to the characteristic melodic second interval, along with the unit Eb-D, preserves its essence, organizing the musical discourse. According to Almén,

"[...] a narrative trajectory [...] appears when a listener can recognize a fundamental opposition within a work and observe its progress and, particularly, its outcome" (Almén 2008, p.70).

According to the Topic Theory, the first motif shows the characteristics of a march $^{17}$, identified by the figure of the dotted-eighth note and staccato articulation, denoting assertiveness ${ }^{18}$, finalized with a decrease that will link the beginning of the second motif, more jocular and with a character rhythmically unstable. Generated by the tuplet, the second motif frequently appears off-beat, creating a clear opposition to the march figure, always presented on-beat. Notice that the pitches D-G-Eb in the final of the second motif are the same of the opening of the work, but presented in different order.

Throughout the first movement, there is a constant interaction between these topical figures, with moments of overlap and dialogue between the instruments. Besides that, the two motifs contain units of neighbor tones compensated by melodic leaps or vice-versa, normally contra directional, a basic contrapuntal procedure. The narrative constructed through the transformation of the cell Eb-D-G - associated with the march topic - and its interaction with the tuplet figure offers the dialectical background that put in confrontation two contrasting moods. Example 3 shows a first stage of transformation of the march motif, nevertheless preserving the content of cell Eb-D-G.

\footnotetext{
17 "Nevertheless, some distinction can usually be drawn between hunting r eferences and military. The most obvious factor is the meter. Hunting calls are almost exclusively in 6/8 time, both in France and in Germany. The signals of the cavalry trumpet, on the other hand, were often in common time" (Monelle 2006, p.82).

18 "We may surmise that the military style carries suggestions of soldiering and thus, perhaps, of heroism and gallantry" (Monelle 2006, p.4).
} 


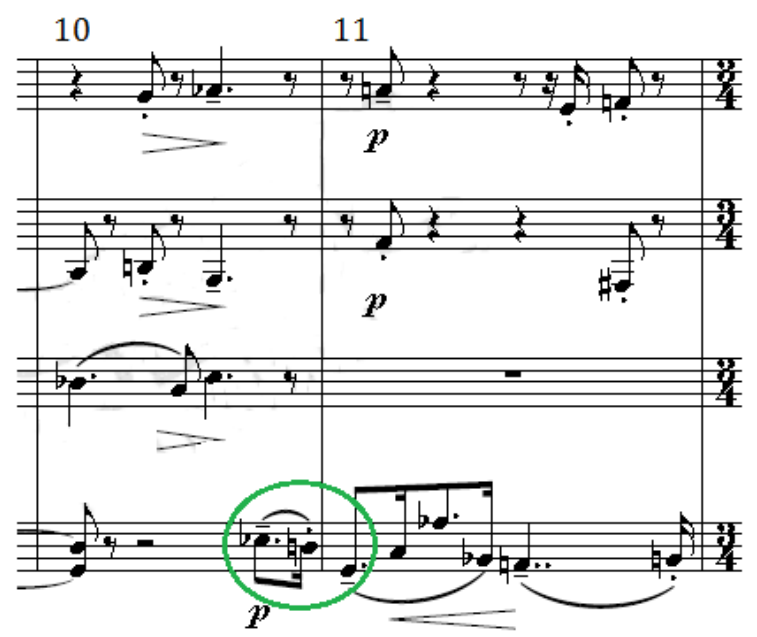

Example 3: Bars 10 and 11 - Development of the first motif

A second transformation of the first motif appears at bar 17 (Example 4), now presented as a tuplet with E natural rather than E flat. Important to notice that two more pitches will be ordered in the same order of the phrase of the beginning: $\mathrm{Ab}$ and $\mathrm{Bb}$. In addition, the tuplet figure that follows organizes the phrase in the same way of the very beginning of the work, creating an expected opposition.

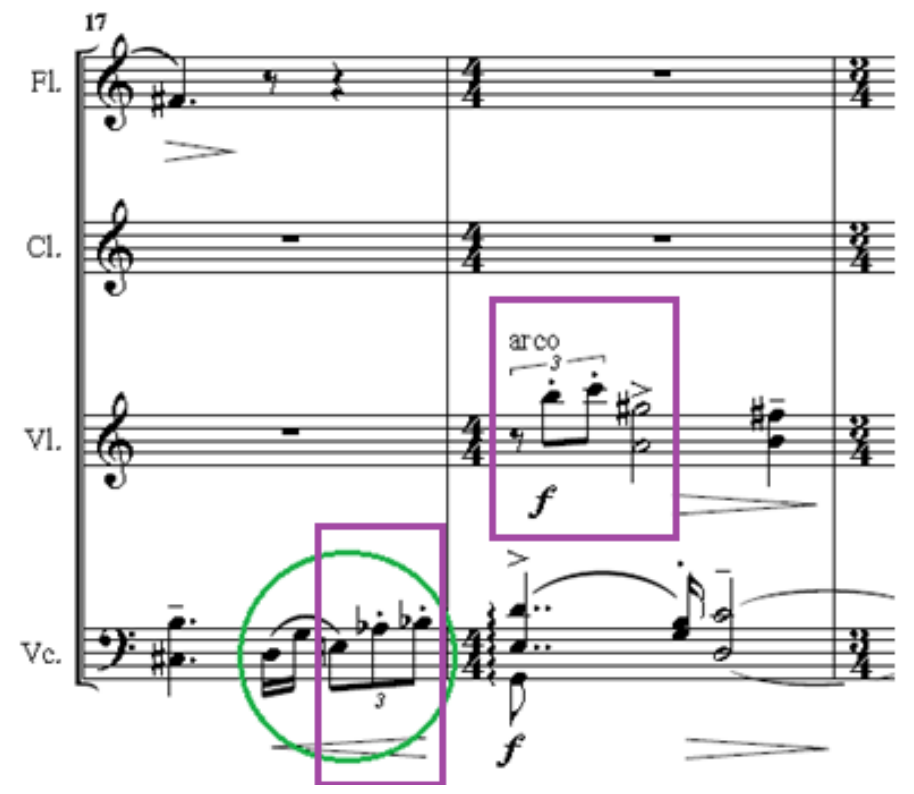

Example 4. Bars 17 and 18: sequence D-G-E (natural) with subsequent $\mathrm{Ab}-\mathrm{Bb}$

At the end of bar 22, there is a third transformation of the motif (Example 5). Notice that all these transformations are in the cello part and this one is especially close to the original motif. In addition, the second topic character always relates to the first motif as a kind of response. 


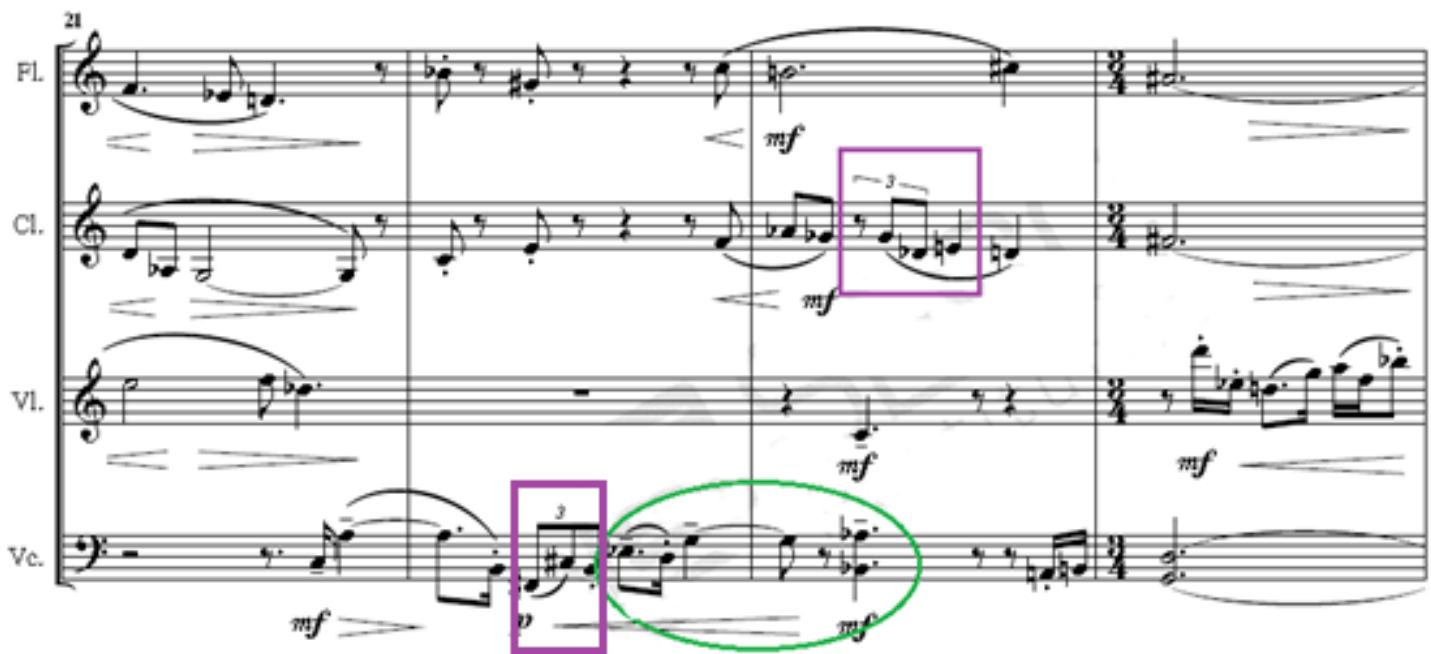

Example 5: Bars 21 to 24: cell Eb-D-G with the same configuration of the beginning, coming from the second topical tuplet motif

A sort of development of this motif appears at bar 30 (Example 6). The same rhythmic figuration of the beginning remains, but the pitches change, and there is greater interaction among the agents, including an overlap of the two motifs that generated the music.

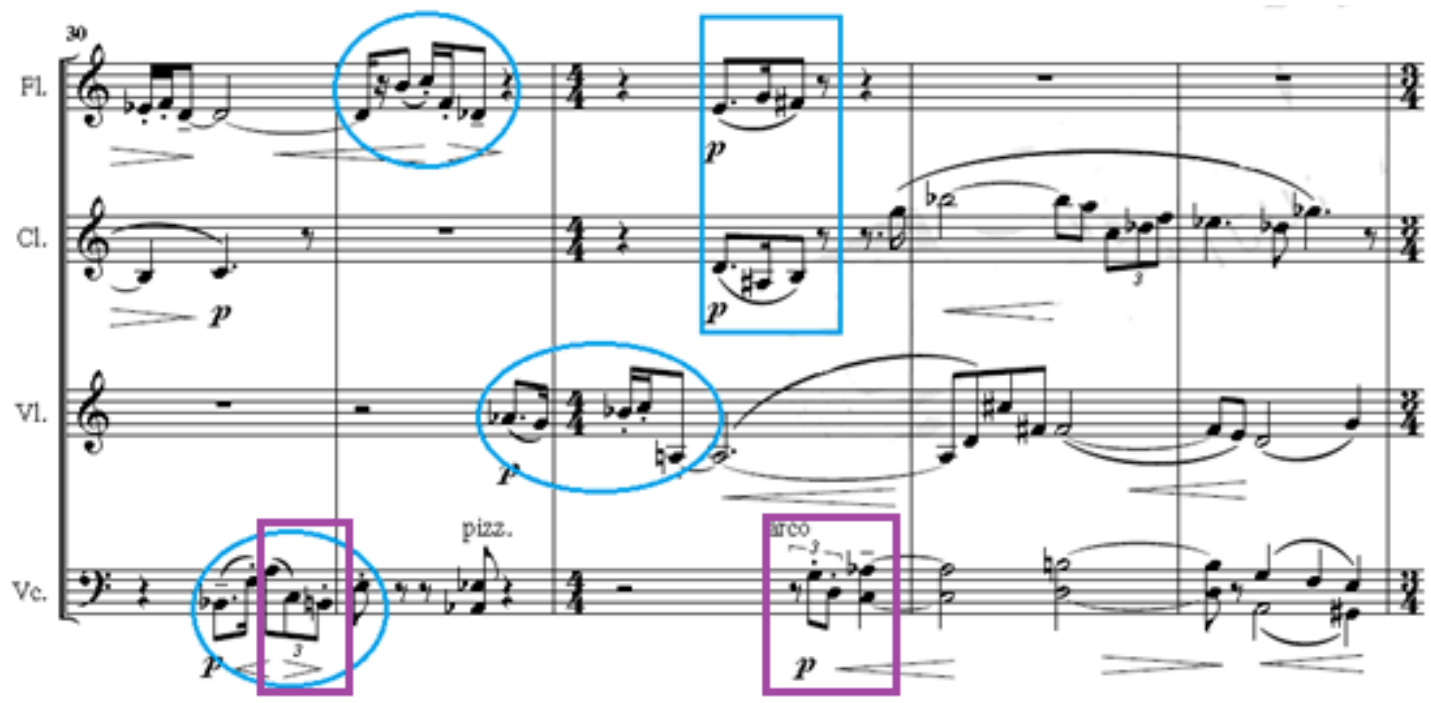

Example 6: Bars 30 to 34

The four instruments interact portraying topical agents, although it is perceptible a certain association of the march topic with the strings and the more cantabile one with the woodwinds. There are several other moments where these two figures appear, but the purpose of this article is only to highlight the conflict between them. Thereby, in the first movement the agents attempt to impose the march topics. The motif figuration associated with them articulates the form at 
the beginning of each new section of dialogues. Gradually they lose their pungency and the texture rarefies. A decay of density and segregation between the woodwinds turns more evident. This liquidation ends in a slow section where harmonic and pizzicati effects predominate, interrupting the narrative, almost as a "truce" in speech (see Example 7).

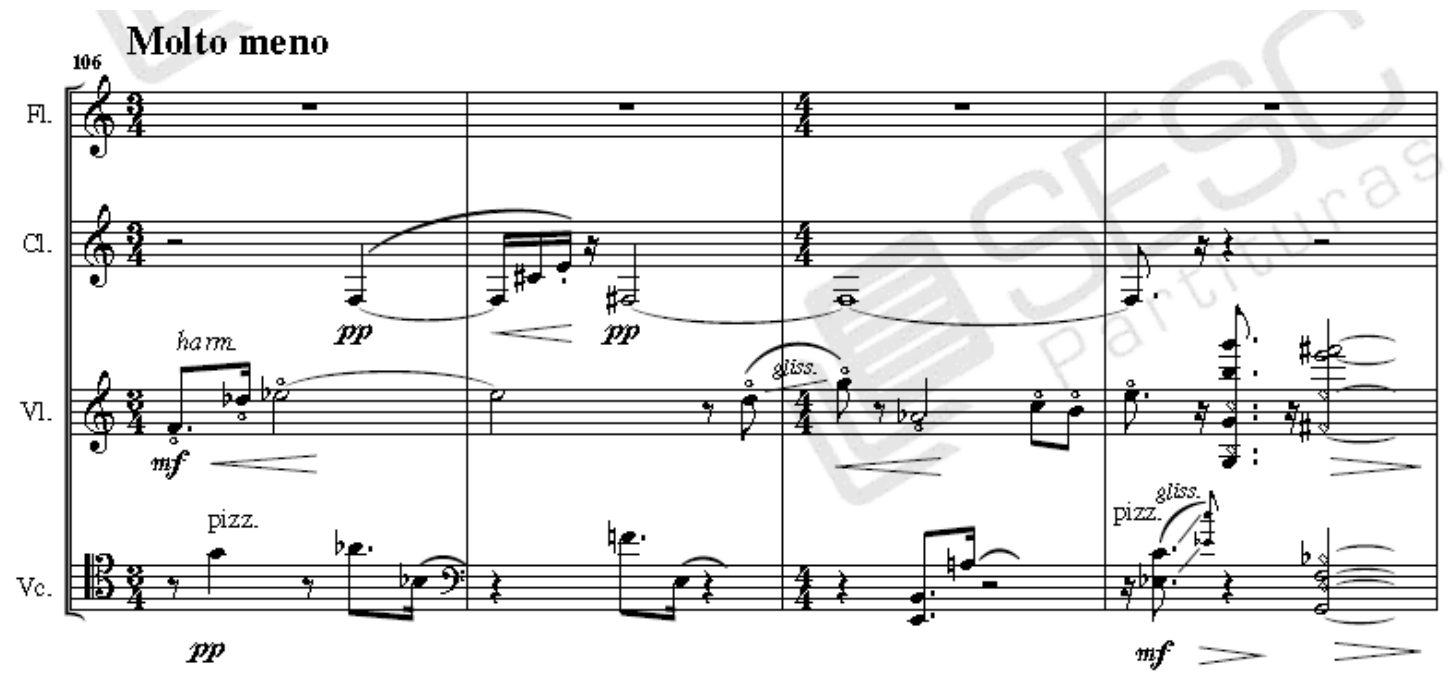

Example 7: Bars 106 to 109: dilution of topical figures

After two fermatas, Tempo I takes over the narrative, this time with the clarinet presenting the march topic, readily overtaken by the strings. There, it is highlighted the exchange between the topics (see Example 8).

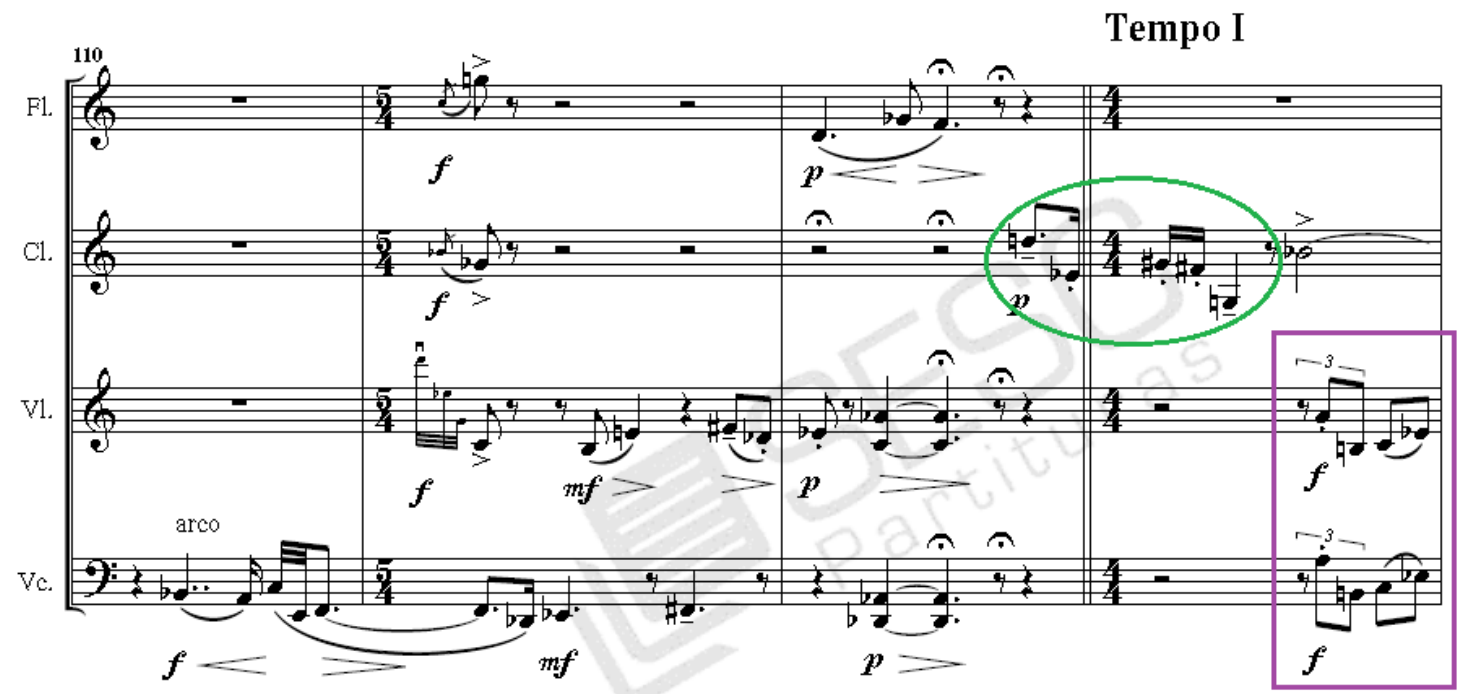

Example 8: Bars 110 to 113: Beginning of Tempo I: the clarinet presents the march topic and strings answer with the second topical motif

The entire Tempo I consists of unison on the strings which portrays a section of apotheosis with the flute reaching the highest pitches of the whole 
movement, indicating that the actors are more decided than ever to hold their positions, and that a conciliation is not expected for the second movement.

In the second movement (Example 9), the conflict intensifies because there is a constant alternation between binary and ternary meters. However, topical figures, still present, are much less sweeping than before and finally fade. As a narrative, it represents a less assertive discourse and from the dynamic point of view the impetus decreases, although the conflict remains on the metrical structure. The characteristic motif configurations of the first movement are still present, but configured like a "weariness" of the locution.

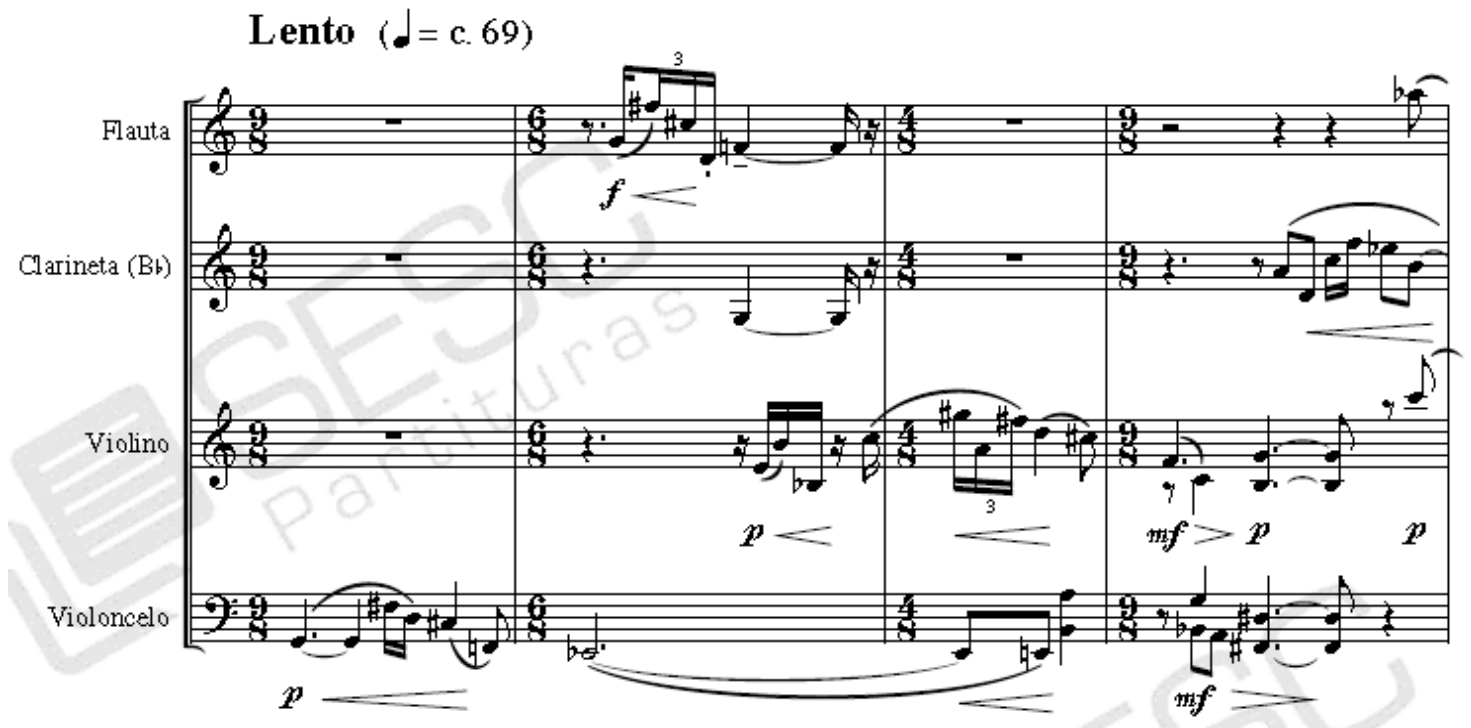

Example 9: 2nd Movement, initial bars

The third movement (Example 10) represents a complement to the first movement, keeping several structural characteristics - such as the slow inner section, full of complex rhythmic events - and bringing back the clash between topics notably the march and the cantabile. The topical structure that initiates the movement, with two clearly defined agents, refers to the beginning of the work. 


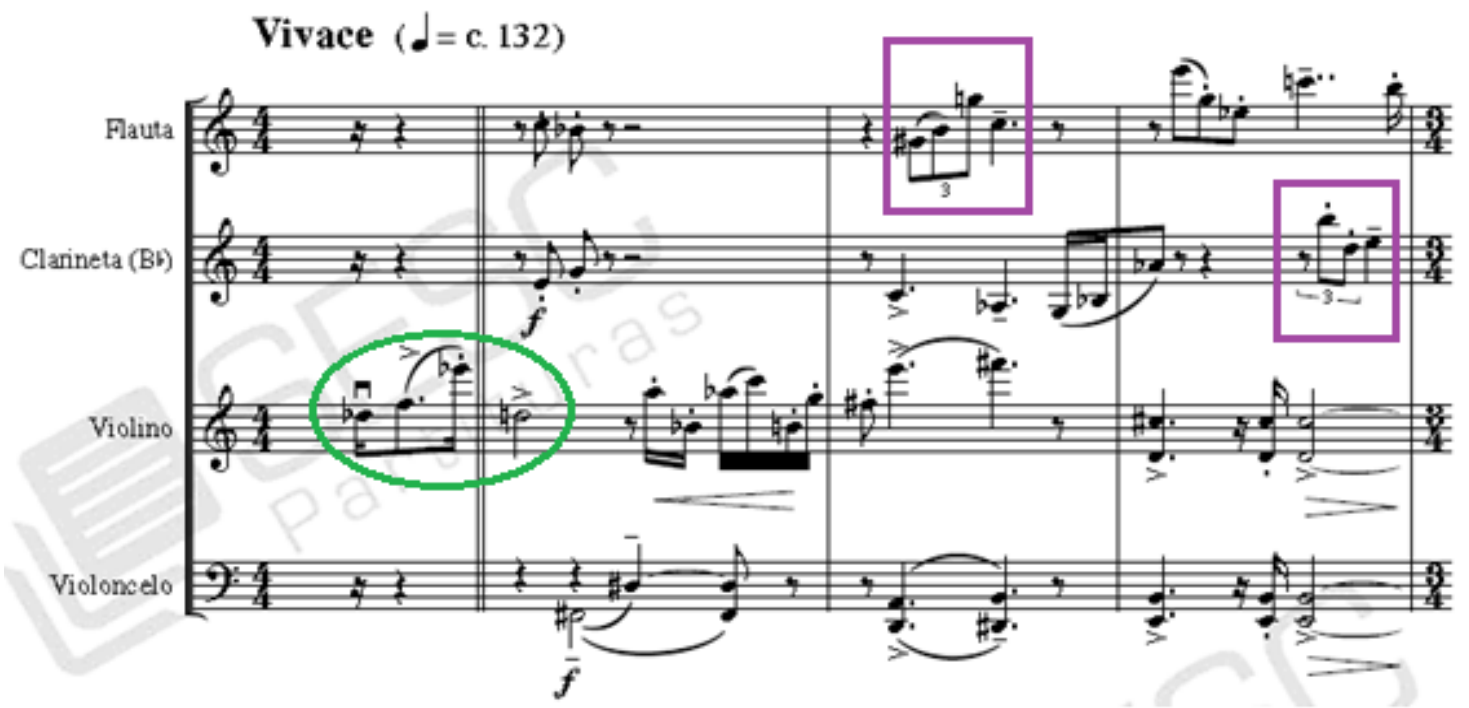

Example 10: 3rd Movement, initial bars, topical relation similar to the first movement

Particularly noteworthy is the Tempo I section starting at bar 54. Initiating with the cello - the same instrument that sustained the whole narrative of the first movement - the music begins to sketch a resolution for the conflict promoting a greater interaction between the different instruments (Example 11).

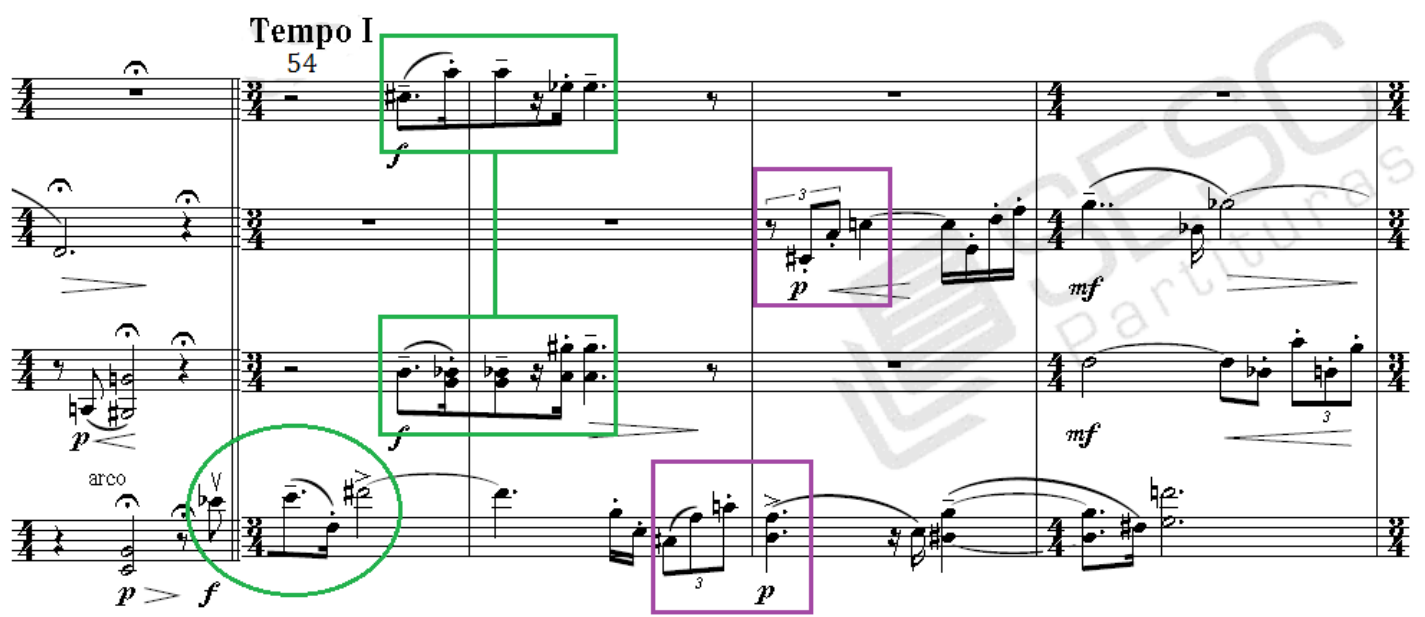

Example 11: Bars 53 to 57: Topical interaction and rhythmic relations between different instruments.

With a strenuous section from bar 58 on (Exemplo 12), the work ends apotheotically, with the violin reaching its highest register, fortissimo dynamics and accents throughout the group. Three measures from the end, there is an abrupt structural cut, and the longest rest of the whole composition. Leading to a ritardando that leads to the group's unique homorhythmicity of the final two measures, the narrative resolves with an "agreement" and an apparent "victory" of the tuplet motif. However, this resolution is ambiguous because it has a rather 
affirmative on-beat character, in the manner of the first motif march topic. It is important to emphasize that this final phrase composed by motivic fragments that gave origin to the topics previously presented and worked out throughout the piece, represents a synthesis of everything and closes the narrative proposed by the composition without a clear resolution of its conflict.

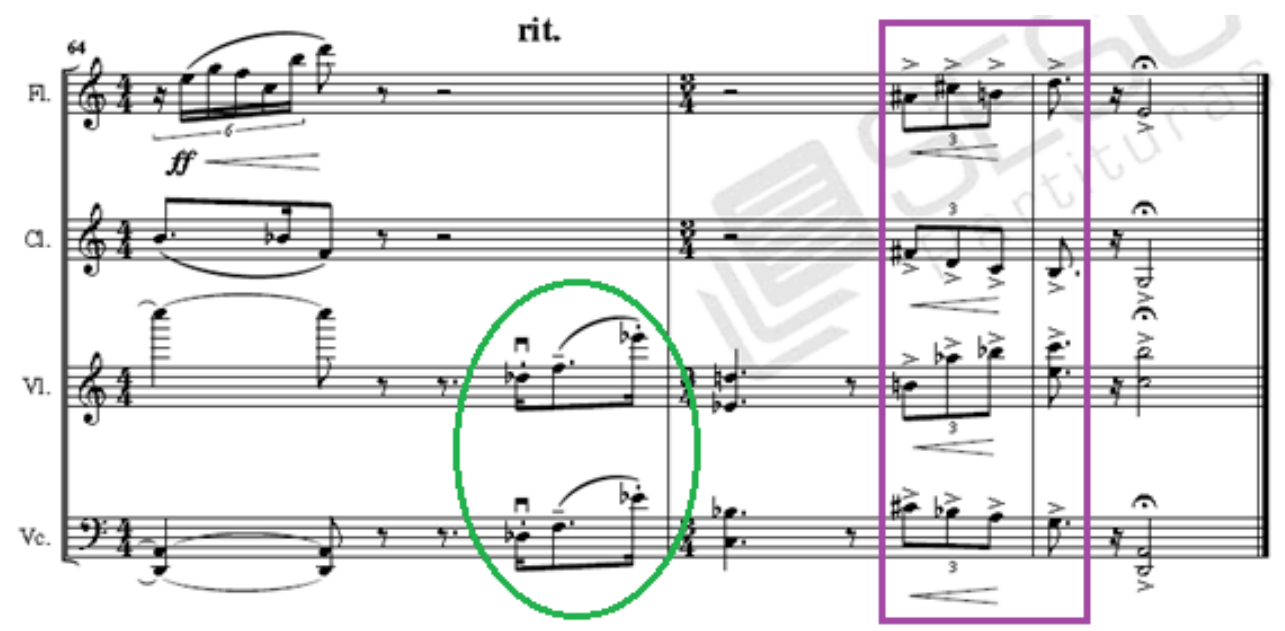

Example 12: Final bars: Caesura, last recapitulation of the march topic and final statement of the second motif as four voices homorhythm

As a whole, the composition presents a clear tripartite distribution, with two fast movements at the extremes and a slow movement in the middle, dialoguing directly with the traditional standard of contrasting tempo sections (fast-slow-fast). In addition, both fast movements have an internal slow section, becoming themselves ternary forms (Table 1).

\begin{tabular}{|l|l|l|l|l|l|l|}
\hline \multicolumn{2}{|l|}{$\mathbf{1}^{\mathbf{0}}$ Mov. (123 c.) } & $2^{\mathbf{0}}$ Mov. (45 c.) & \multicolumn{3}{l|}{$\mathbf{3}^{\mathbf{0}}$ Mov. $(66$ c.) } \\
\hline $\begin{array}{l}\text { Allegro } \\
\text { (c.120 bpm) }\end{array}$ & $\begin{array}{l}\text { Molto } \\
\text { meno }\end{array}$ & Tempo I & $\begin{array}{l}\text { Lento } \\
\text { (c. } 69 \mathrm{bpm})\end{array}$ & $\begin{array}{l}\text { Vivace } \\
\text { (c. } 132 \mathrm{bpm})\end{array}$ & $\begin{array}{l}\text { Larghetto } \\
\text { (c. } 50 \mathrm{bpm})\end{array}$ & Tempo I \\
\hline
\end{tabular}

Table 1: Formal scheme of the work that demonstrates its ternary relations

\section{5 - Conclusion}

The concept of narrativity in music embraces a problematic vocabulary due its usage originally in literature. However, the Topic Theory enables the transposition of some valid notions in order to assist a structural analysis. In this Quartet, its application made possible to highlight two main actorial figures and to detect a typical narrative conflict. Putting these contrasting elements in 
opposition, a narrative emerges through the integration, variation, superposition, juxtaposition, fragmentation and disintegration of these figures, generating the constructive logic of the work's formal organization. Thus, applied to an almost unknown work of the twelve-tone repertoire, written by an important Brazilian composer of the twentieth century, the narrative analysis proved to be an useful tool for elucidating formal schemas and the role of expressivity in the discourse, encouraging reflection and understanding of the compositional process.

\section{References}

1. Agawu, Kofi. 2009. Music as Discourse: Semiotic Adventures in Romantic Music. New York: Oxford University Press.

2. Almén, Byron. 2008. A Theory of Musical Narrative. Bloomington: Indiana University Press.

3. Assis, Ana Cláudia de. 2006. Os Doze Sons e a Cor Nacional: Conciliações Estéticas e Culturais na Produção de César Guerra-Peixe (1944-1954). Tese de Doutorado.

4. 2010. César Guerra-Peixe: entre Músicas e Músicos (19441949). Revista do Conservatório de Música da UFPel, nº3, p. 58-79.

5. Botelho, Flávia Pereira. 2013. Guerra-Peixe e a Busca pela Renovação do Nacionalismo Musical: Reflexos na Obra para Piano. Tese de Doutorado.

6. Coelho de Souza, Rodolfo. 2011. A Recepção das Teorias do Dodecafonismo nos Últimos Quartetos de Cordas de Cláudio Santoro. Revista Brasileira de Música, v. 24, n. 2, p. 329-350.

7. Egg, André. 2004. O Debate no Campo do Nacionalismo Musical no Brasil dos Anos 1940 e 1950: o Compositor Guerra Peixe. Dissertação de Mestrado.

8. 2006. A Carta Aberta de Camargo Guarnieri. Rev. cient./FAP, v.1, p.1-12, jan/dez.

9. Galerias Comerciais no Rio de Janeiro e em São Paulo até 1970. 2017. In: Enciclopédia Itaú Cultural de Arte e Cultura Brasileiras. São Paulo: Itaú Cultural. Disponível em: 
$<$ http://enciclopedia.itaucultural.org.br/termo5400/galerias-comerciais-norio-de-janeiro-e-em-sao-paulo-ate-1970>. Access: June 26, 2017.

10. Guerra-Peixe, César. 1971. Curriculum Vitae-Catálogo de obras. Belo Horizonte: Biblioteca da Escola de Música da UFMG, VI. 21 f.

11. Quarteto Misto (full score with individual parts).

Available at: https://painelsesc.sesc.com.br/partitura s.nsf/viewLookupPartituras/618476A 649EAD5FA832579DC006F13C1/\$FILE/quarteto_misto.pdf

12. Hartmann, Ernesto. 2011. Dodecafonismo, Nacionalismo e Mudanças de Rumos: uma Análise das 6 Peças para Piano de Cláudio Santoro e das Miniaturas n. 1 para Piano de Guerra-Peixe. Opus, v. 17, n. 1, p. 97-132.

13. 2013. O Melos e Harmonia Acústica (1988) de César Guerra-Peixe, Koellreutter e Hindemith: Similaridades e Princípios Básicos. Per Musi, n. 27, p. 50-60.

14. Hatten, Robert. 1994. Musical Meaning in Beethoven: Markedness, Correlation, and Interpretation. Bloomington: Indiana University Press.

15. 1991. On Narrativity in Music: Expressive Genres and Levels of Discourse in Beethoven. Indiana Theory Review Vol. 12, p. 75-98.

16. Kater, Carlos. 2001. Música Viva e H.J. Koellreutter. Movimentos em Direção à Modernidade. São Paulo: Musa Editora e Através.

17. Malamut, Stael Viegas. 1999. A Flauta no Período Dodecafônico de Guerra-Peixe. Anais do Congresso da ANPPOM de 1999 (PDF on-line).

18. Micznik, Vera. 2001. Music and Narrative Revisited: Degrees of Narrativity in Beethoven and Mahler. Journal of the Royal Musical Association, 126, p. 193-249.

19. Monelle, Raymond. 2006. The Musical Topic: Hunt, Military and Pastoral. Bloomington: Indiana University Press.

20. Nattiez, Jean-Jacques. 1990. Can One Speak of Narrativity in Music? Journal of the Royal Musical Association, V. 115 no 2, p. 240-257. 
21. Pasler, Jann. 2008. Writing through Music: Essay on Music, Culture, and Politics. Oxford: Oxford University Press.

22. Ricoeur, Paul. 1984. Time and Narrative. Chicago: Chicago University Press.

23. Tarasti, Eero. 1994. A Theory of Musical Semiotics. Bloomington: Indiana University.

24. Vetromilla, Clayton Daunis. 2002. Introdução à Obra para Violão Solo de Guerra-Peixe. (Incluindo gravação integral e edição crítica da Suíte). Dissertação de Mestrado.

25. Walsh, Richard. 2011. The Common Basis of Narrative and Music: Somatic, Social, and Affective Foundations. Storyworlds: A Journal of Narrative Studies, Vol. 3, p. 49-72. 